\title{
Enhancing the competitive advantage for tourist souvenirs in Egypt: a marketing approach
}

Ghada Abdallah Mohamed $^{1 *}$, Nour Elhoda Ali Mahmoud ${ }^{2}$, Hebatullah Atef Alakhras ${ }^{3}$

Faculty of Tourism and Hotels, Suez Canal University, Ismailia, Egypt ${ }^{1,2,3}$

drg.abdalla@yahoo.com ${ }^{1 *}$, nourali2129@gmail.com ${ }^{2}$, heba_alakhras@ tourism.suez.edu.eg ${ }^{3}$

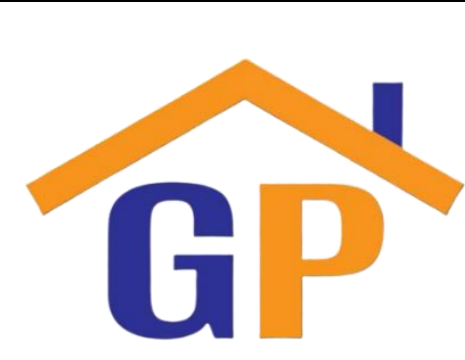

Article History

Received on 25 March 2021

Revised on 11 April 2021

Accepted on 13 April 2021

\begin{abstract}
Purpose: The main aim of this research is to study the relationship between innovative marketing - in its various dimensions (innovation in product, innovation in price, innovation in promotion, innovation in distribution) - and enhancing the competitive advantage of tourist souvenirs in Egypt.
\end{abstract}

Research methodology: The study adopted the descriptiveanalytical approach for accurate and detailed descriptions of the study's subject quantitatively and qualitatively and analyzed data available on this subject. The field study included surveying a random sample of tourists who frequented the souvenirs and handicrafts stores in various tourist cities in Egypt.

Results: There is a statistically significant effect of innovative marketing in enhancing tourist souvenirs' competitive advantage in Egypt. Overall findings highlighted that all the hypotheses were accepted.

Limitations: The repercussions of the COVID-19 virus crisis reduced the scope of the study to only tourists in South Sinai and Red sea Governorates; whereas, tourist souvenirs stores were allowed to operate in accordance with the precautionary measures in only three main governorates: the Red Sea, South Sinai, and Marsa Matrouh, in addition to some gift shops in major hotels.

Contribution: The study findings provide guidelines for practitioners within the tourist souvenirs and handicrafts sector to undertake the results and adapt them to assess and enhance their performance. Thus, they could improve their competitiveness.

Keywords: Tourist souvenirs, Innovative marketing, Competitive advantage

How to cite: Mohamed, G. A., Mahmoud, N. E. A., \& Alakhras, H. A. (2020). Enhancing the competitive advantage for tourist souvenirs in Egypt: a marketing approach. Journal of Sustainable Tourism and Entrepreneurship, 2(1), 15-29.

\section{Introduction}

The current era is characterized by the increasingly rapid pace of innovation and the emergence of new products with a short life cycle. In the light of changes in the economic situation of a large increase and constantly change in competition and a huge development in technology and innovative processes, it became necessary to all organizations to develop new or improved products to satisfy customers' needs and meet their desires. Ionescu and Dumitru (2015) confirmed that innovation is the leading force of competitiveness and growth, and it is a great opportunity for marketing specialists to leave their mark on the organization, to take essential attempts based on the deep understanding of the opportunities presented by the market and the customers' needs, to be close to the strategic challenges and opportunities. In particular, the tourism activity has been affected by the complex and competitive business environments and the changing marketing activities, it has become essential for all elements in the tourism sector to devise new and constantly changing marketing strategies to be able to face regional and international competition, and this includes innovation in the elements of the tourism 
industry such as tourism programs, activities, prices, and services, in addition to one of the most important tourism components in many tourist destinations which is 'tourist souvenirs'.

The souvenir is a great part of the travel experience; when a tourist visits any country he looks for authentic souvenirs with quality and meaning, to chronicle his visit and share the experience with his friends and family by bringing them a small keepsake of the tourist destination. According to Yoshiyuki (2010) shopping souvenirs and residence places should be reinforced because these factors have very high chances for economic effects. At the same time, if these factors were amended well, they would be contributed to the improvement of the quality of tourism. Due to the competition faced by the traditional souvenirs and crafts in Egypt - especially with the Arab countries neighboring Egypt because of the diversity of cultural heritage in many Arab countries -, it is necessary to innovate in the marketing efforts and to create an integrated marketing mix that contributes to creating a renewable and sustainable competitive advantage that enables these original Egyptian products to remain, besides enhancing the competitive advantage of Egypt as a distinguished tourist destination. Successful marketing strategies of souvenir stores require innovation in the marketing mix (product/service, place, price, and promotion) that will best satisfy customers' needs.

\section{Problem statement}

Despite the importance of the souvenirs for the tourism activity in any tourist destination and to the Egyptian tourist destination, in particular, Egyptian souvenir has major problems such as; the intense competition with imported tourist souvenirs and the competition with neighboring Arab countries whose souvenirs are distinguished by quality and perfection, in addition to the insufficiency of the marketing strategies of the Egyptian souvenirs. As a result, the Egyptian souvenirs cannot achieve the competitive advantage that it deserves, and it has become imperative for all elements in the activity of Egyptian tourist souvenirs to look forward and to adopt innovative strategies to face the changing circumstances that enable them to achieve competitive advantages to face this competitive crowd. So far, the literature on innovative marketing strategies for traditional souvenirs and crafts is rare. For that reason, this study addresses this gap and explores the possibilities of innovation strategies for the traditional souvenirs and crafts industry.

\section{Research objectives}

i. Identifying the importance of tourist souvenirs and how it contributes to distinguishing the Egyptian tourist destination.

ii. Studying the relationship between innovative marketing in its various dimensions (innovation in product, innovation in price, innovation in promotion, innovation in place), and enhancing the competitive advantage of souvenirs in Egypt.

\section{Literature review and hypothesis development}

\subsection{Tourist souvenirs}

\subsubsection{Definition of souvenirs}

The definition of "souvenir" varies among dictionaries and researchers, but most definitions point out a similar meaning. According to the Macmillan dictionary, the word 'souvenir' refers to "something that you buy during a holiday or at a special event to remind you later of being there". (Souvenir," n.d.). Singh (2018) illustrates that the word 'souvenir' comes originally from the French language from the verb 'se souvenir de' meaning 'to remember. The term 'souvenir' was usually connected to the tourism field; that is because tourists always buy souvenirs as tangible evidence and a reminder of their travel experience, while other tourists buy them as gifts for family or friends. In a study by Wilkins (2010), it was suggested that a souvenir might be a gift, a memory, or evidence. A tourist buys a souvenir as a gift for him/herself or others, such as relatives, colleagues, and friends. As a memory, a souvenir is bought for reminding special occasions or events during the journey. In contrast, a souvenir as evidence is usually used as approval that someone has achieved a special experience. 


\subsubsection{Types of souvenirs}

The souvenir may be one of the various forms such as postcards, T-shirts, objects of nature, local crafts, fine art, wearable art, accessories, jewelry, toys, and other items (Marzouki, 2020). And since the current study targets the Egyptian tourist destination, it is worth noting that Egyptian tourist souvenirs take several forms, the most important of which are; copper carving products, brass plates, Egyptian cotton garments, silverware (Jewelry, cartouches, artifacts), golden ornaments, papyrus papers and paintings, tasty spices, perfume essence sold in oriental bottles, Islamic crafts, postcards, and other handmade items, in addition to mini statues which represent different forms of gods, kings, queens, and symbols from ancient Egyptian times. For instance, a statue of King Ramses II, King Tutankhamon, Queen Nefertiti, Pyramids ...etc. (Marzouki, 2020 ; ElSamadicy\&Amara, 2011).

\subsubsection{Importance of souvenirs}

Tourist souvenirs have great importance, and the benefits from buying souvenirs reflect on the economy, the host community, culture, and the environment. These benefits include both the destination (supply) and the tourist (demand). According to Dawood and Bahaa (2019), the importance of souvenirs for the destination from the supply side includes: generate employment opportunities, underlining competitive advantages, raising incomes, playing a role as indirect marketing, conserving identity and cultural features, and finally preserving ancient traditional crafts industries for future generations, which all related to sustainability. As for the demand side represented by tourists, souvenirs promote having a tangible reminder of a delightful time, a remarkable experience of meeting people, customs, traditions, places, and keep memories related to travel.

Souvenirs also contribute to conserving and creating the destination's image; as tourists can give them as gifts to their family and friends or can use them as evidence of visiting this destination. Therefore, they act as a promotion tool for this destination and contribute to raising its attractiveness, history, sightseeing, and preserving its image (Dumbrovska \& Fialova, 2019). A study about the role of brand authenticity in Egyptian destination marketing held by Ibrahim, Hilaly and Morsy, (2018) stated that souvenir is one of the important components of the travel experience which enhance identity, reflect destination image and stir positive memories of tourist vacation. Thus, souvenirs rebuild authenticity by transferring the authenticity ingrained in cultural and historical elements. Traditional souvenir craft industries are mostly based on the material of the product. Therefore, they can apply an identity-driven marketing strategy by producing products focusing on highlighting local authenticity in high-quality work of craftsmanship (Zulaikha\& Bereton, 2011).

Regarding the economic importance of souvenirs, they are economically important for many retail businesses located near or at a tourist site (Swanson ,2004). Dawood and Bahaa (2019) stated that tourists spend about one-third of their tourism expenditure on shopping. According to (Radwan \& Jones, 2015) selling souvenirs has been considered a way for communities to benefit economically from tourism. The economic benefit of souvenir selling depends on the origin of the souvenirs. Handmade souvenirs in Egypt's tourist markets increase the economic benefit to the local community better than imported souvenirs, particularly from China increasingly sold beside the handmade souvenirs. Whereas the sale of imported souvenirs contributes to leakage of revenue from the local community, it is essential to improve traditional handmade souvenirs to stand in front of this competition.

\subsection{Innovative marketing}

Innovative marketing is defined as "the implementation of a new marketing method involving significant changes in product design or packaging, product placement, product promotion, or pricing" (Cascio,2011, p. 11). According to Sattari and Mehrabi (2016), innovative marketing is considered as "doing something new with new ideas, new products or new technology and refining these ideas in response to the market demand, according to a new method" (p.80). Besides, they illustrated that the innovative marketing would be reactive as a result of the continuous changes, or supportive improvements based on the existing activities. 
Ilic, Ostojic and Damnjanovic (2014) stated that marketing innovation includes using new marketing strategies, concepts, or methods that the organization has never applied. They are based on combining the following elements: notable product improvements, carrying out new pricing strategies, carrying out a new retail concept, and carrying out a new promotion concept. Innovative marketing is not only concerning developing new products, services, and technologies but also is one of the main factors that an organization can use to successfully meet customers' needs, compared with its competitors. Thus it could construct a competitive advantage in the intensively competitive business environment (Sattari\& Mehrabi, 2016).

\subsection{Competitive advantage}

\subsubsection{The concept of competitive advantage}

Kotler defined the competitive advantage as "an organization's ability to perform in one or more ways that competitors will not or cannot match" (Quporsi, 2010, p.54). According to Cegliński (2017) competitive advantage was achieved when an organization obtains a set of features that allows it to exceed its competitors. In other words, competitive advantage was disclosed when the organization activities are more profitable than its competitors' activities or when it outperforms them regarding other outstanding results of activities. Besides, it is acquired by the organization's effective marketing strategy, the execution of this strategy, and the context in which competition was revealed (Quporsi, $\underline{2010)}$.

\subsubsection{Souvenirs' competitive advantage}

To identify the most important specifications that can be considered as competitive advantages for the tourist souvenirs activity, market and consumer research must be carried out to understand the customers' desires and needs. However, there are a number of factors that can distinguish the activity of tourist souvenirs from which it gains a competitive advantage that distinguishes it from competitors and motivates tourists to buy; according to $\underline{\text { Swanson (2004), these factors include: }}$

- product characteristics (quality, uniqueness, variety, functional importance, design, packaging, innovation)

- price characteristics (competitive prices, value for money, special offers)

- place/ distribution channel characteristics (location, visual appeal, ease of movement, store appearance)

- promotion characteristics (salespeople quality, advertising, promotional offers, special in-store events)

\subsection{Innovative marketing relationship with the competitive advantage}

Innovation is a primary source of a competitive advantage that determines the economic success of any organization. If an organization wishes to survive and grow in today's unsettled business environment, it has to make every effort to introduce an innovative and creative approach (Urbancova, 2013). and Algadeer (2004) stated that marketing innovation reflects the organization's ability to improve products/services continuously, which leads to achieving great and new benefits to its customers and uniquely satisfy their needs. In return, this may result in creating a competitive advantage for the organization and distinguishing the firm from its competitors by identifying customers' needs and translating them into realities. The study's findings by Alsamydai, Alnawas, and Yousif (2010) confirmed that there is a positive relationship between the innovation in the marketing mix (product, price, promotion, and place) and creating a sustainable competitive advantage.

Therefore:

$\mathbf{H}_{1}$ : There is a relationship between innovative marketing and the competitive advantage of tourist souvenirs in Egypt 


\subsubsection{The relationship between product innovation and the competitive advantage}

A study by Mburu(2016) found that there is a positive relationship between innovation strategies and the organizations' competitive advantage. The study concluded that product innovation is essential to enhance the competitiveness of the organization. Therefore, competitive advantage level variability decisions should take into account the inclusion of innovation strategies. Reguia (2014) emphasized that and stated that the continuation and the stability of any organization depend on its capability to maintain its marketplace and face the competition which spreads rapidly and aggressively with globalization and the expansion of new technologies. And while the product reflects the organization's image, its whole success also relies on the product success through achieving customers' desires and needs and developing new products.

Therefore:

H1a: There is a relationship between product innovation and the competitive advantage of souvenirs in Egypt.

\subsubsection{The relationship between innovation in price and the competitive advantage}

Hinterhuber and Lizou (2014) assured that innovative pricing is one of the most powerful sources of competitive advantage. Based on a group of interviews they had conducted with CEOs and top management personnel, as well as analysis of the pricing practices at leading companies in the U.S., Europe, and Asia, they estimated that less than 5\% of companies applied innovation to their pricing strategy, tactics, or organization. Their research showed that companies that carry out innovation to their pricing activities outperform their competitors significantly. Alsamydai et al., (2010) stated that the development of pricing processes is the most promising strategy when increasing volumes is hard to achieve in a saturated market. The study found that a $2 \%$ price increase would be translated into double profit growth for many organizations.

Therefore:

H1b: There is a relationship between innovation in price and the competitive advantage of souvenirs in Egypt.

\subsubsection{The relationship between innovation in the promotion and the competitive advantage}

Alsamydai et al., (2010) mentioned that innovative promotion can affect positively on brand choice and purchase quantity, this in return, might lead to having a sustainable competitive advantage on the long term. Sattari and Mehrabi (2016) stated that the innovative marketing strategies that the organization performs, especially, strategies based on promotional activities and sales promotion, lead to innovations in the products or services offered by the organization and to a competitive advantage as well

Therefore:

H1c: There is a relationship between innovation in the promotion and the competitive advantage of souvenirs in Egypt.

\subsubsection{The relationship between innovation in place and the competitive advantage}

Distribution channels are pathways along which products traverse from producers or manufacturers to the end consumers. It can include wholesalers, retailers, distributors and even the internet (Mahasuar, 2019, p13). It was found that innovation in certain distribution channel functions enhanced the efficiency of the distribution channel, which eventually improves the performance. That also has great implications on a firm's competitive advantages. (Kuswantoro, Mohd, Abdul\& Ghorbani, 2012). Alsamydai et al., (2010) stated that innovating in the distribution channels affect positively on customer satisfaction and the organization performance; this leads to having a sustainable competitive advantage Therefore:

H1d: There is a relationship between innovation in place and the competitive advantage of souvenirs in Egypt. 


\section{Research methodology}

According to the nature of the subject, the study adopted the descriptive-analytical approach, for an accurate and detailed description of the subject of the study quantitatively and qualitatively, in addition to analyzing data and information available on this subject. A field study was conducted to test the validity of the study hypotheses by revealing the reality of marketing practices in the tourism souvenir activity, the extent of applying innovative marketing methods, and the impact of these practices on the competitive advantage of Souvenirs in the Egyptian tourist destination. A questionnaire form was distributed to a random sample of 450 tourists visiting the souvenir and handicraft stores. 418 forms were collected and 400 forms were valid and analyzed.

\section{Development of survey instrument}

The questionnaire was divided into two sections, as follows:

The first section included the demographic characteristics of the respondents

The second section included questions related to the study variables: applying innovative marketing methods in tourist souvenir stores and the availability of competitive advantages in the Egyptian tourist souvenir activity. All questionnaire items were measured with a 5-point Likert scale between $1=$ strongly disagree and $5=$ strongly agree.

Tourism works of literature were reviewed and relevant measurement factors were adapted to the questionnaire of this study. The marketing mix variables are the popular 4Ps (product, price, place and promotion) According to Heroux and Gultek (2016), Swanson (2004), Wicks (2004), and Gahring et al. (1992) tourist souvenirs marketing mix variables are subdivided in this study as follows:

\section{Product variables:}

Breadth of product line, selection and variety, size and ability to carry and travel with, quality, private local made and authentic, items can be used, and customer services.

Price variables:

Group reductions, bundle or value pricing (packages offered), variety of payment options, coupons/rebates, and competitive prices.

\section{Promotion variables:}

Diversity of advertising tools, internet, special promotions (sales, coupons, contests), advertising features, and free services.

Place variables:

Primary/secondary road (visibility and ease of access), outside appearance, interior layout, labels and signage, visual displays, items arrangement, and salespeople characteristics.

As for the competitive advantage variables based on previous literature, these variables were formulated as follows: (Krajewsky, Malhotra \& Ritzman, 2012), (Awwad, Khattab and Anchor, 2013) and (Jitpaiboon, 2014)

Cost:

The ability to manage effectively production cost, including its related aspects such as overhead and inventory, and value-added.

Quality:

Low-defect rate, product performance, reliability, and service quality.

Time:

How quickly and accurate a product or a service is delivered to customers.

\section{Flexibility:}

The adjustment ability on design/planning, volume changes, and product variety.

An additional variable was added by Hosseini, Soltani and Mehdizadeh (2018) and Dirisu, Iyiola and Ibidunni (2013), which is 


\section{Uniqueness:}

Special features of the product that competitors cannot obtain.

\section{Data analysis}

The raw data were analyzed using Statistical Package for Social Sciences (SPSS) software. The questionnaire variables were analyzed through descriptive statistics measures represented by the arithmetic mean, standard deviation and exploratory factor analysis (EFA). In addition to alpha Cronbach's method to test the reliability and internal validity for responses of the research sample as shown in table (1):

Table 1. reliability and validity statistics

\begin{tabular}{|l|l|l|}
\hline No. of items & Cronbach's alpha & Validity \\
\hline 35 & 0.879 & 0.938 \\
\hline
\end{tabular}

\section{Results and discussion}

\subsection{Demographic characteristics of the respondents}

Table 2. Gender, age and nationality distributions of the respondents

\begin{tabular}{lll}
\hline & Frequency & Percentages \% \\
\hline Sex & & \\
\hline Male & 146 & 36.5 \\
Female & 254 & 63.5 \\
Total & $\mathbf{4 0 0}$ & $\mathbf{1 0 0}$ \\
\hline Age & & \\
\hline $18-25$ & 4 & 1 \\
Over 25 - 35 & 94 & 23.5 \\
Over 35 - 45 & 222 & 55.5 \\
Over 45 - 55 & 66 & 16.5 \\
Over 55 & 14 & 3.5 \\
Total & $\mathbf{4 0 0}$ & $\mathbf{1 0 0}$ \\
\hline Nationality & & \\
\hline European & 224 & 56 \\
Asian & 10 & 2.5 \\
American & 138 & 34.5 \\
Arab & 24 & 6 \\
Other & 4 & 1 \\
Total & $\mathbf{4 0 0}$ & $\mathbf{1 0 0}$ \\
\hline
\end{tabular}

The data in table (2) shows that $63.5 \%$ of the respondents were females, while $36.5 \%$ were males. This is consistent with the mental image that women are more forthcoming to shop and buy than males. The data as well shows that $55.5 \%$ of the respondents were in the age group (over 35 to 45 ), $23.5 \%$ were (over 25 to 35), 16.5\% within (over 45 to 55), and the rest percentage was distributed between the age groups less than 25 years and over 55 years. The data in the table further presents the nationalities of the respondents, and it shows that the highest percentage of respondents were Europeans reaching 56\%, followed by $34.5 \%$ were Asians, while the rest percentage was distributed among Arabs, Americans, and other nationalities 


\subsection{Applying innovative marketing methods in tourist souvenir stores}

Table 3. Product innovation in souvenir stores

\begin{tabular}{|l|c|c|c|}
\hline \multicolumn{1}{|c|}{ Product innovation dimensions } & Mean & $\begin{array}{c}\text { Standard } \\
\text { deviation }\end{array}$ & $\begin{array}{c}\text { EFA factor } \\
\text { Loading }\end{array}$ \\
\hline $\begin{array}{l}\text { Souvenirs stores in Egypt provide a variety of } \\
\text { souvenirs }\end{array}$ & 2.57 & 1.08 & 0.827 \\
\hline $\begin{array}{l}\text { Souvenirs in Egypt are renewed and developed } \\
\text { constantly }\end{array}$ & 2.15 & 0.85 & 0.840 \\
\hline Souvenir stores in Egypt provide multi-use products & 2.38 & 0.80 & 0.677 \\
\hline Souvenirs in Egypt are of a high quality & 1.65 & 1.09 & 0.889 \\
\hline Souvenir stores constantly display handmade items & 3.83 & 0.79 & 0.545 \\
\hline $\begin{array}{l}\text { Souvenir stores collect customer reviews about the } \\
\text { products they prefer or they would like to have }\end{array}$ & 1.94 & 0.75 & 0.506 \\
\hline Souvenirs in Egypt are easy to carry and pack on a trip & 3.34 & 0.93 & 0.766 \\
\hline
\end{tabular}

The data in table (3) shows the respondents' answers on the dimensions of innovation in the souvenir product, and most of the answers tend to "disagree". The arithmetic mean of the product innovation's dimension was (2.55), and the standard deviation (1.16), from which we conclude that the degree of respondents' agreement with this dimension is "low", indicating that most of the sample members do not see any innovation in souvenir products in Egypt.

The respondents' answers to the phrase concerning souvenirs' quality in Egypt are consistent with the findings of the study by Dawood and Bahaa (2019) about the poor quality of some souvenirs in the tourist market in Luxor governorate, where $18.2 \%$ of the respondents were exposed to fraud in the quality of souvenirs.

Table 4. Innovation in price in souvenir stores

\begin{tabular}{|l|c|c|c|}
\hline \multicolumn{1}{|c|}{ Innovation in price dimensions } & Mean & $\begin{array}{c}\text { Standard } \\
\text { deviation }\end{array}$ & $\begin{array}{c}\text { EFA factor } \\
\text { Loading }\end{array}$ \\
\hline Souvenir stores offer price discounts for some products & 3.25 & 0.91 & 0.822 \\
\hline Souvenir stores set new prices on some occasions and events & 3.25 & 0.81 & 0.840 \\
\hline souvenirs prices vary widely among stores & 4.20 & 0.84 & 1.114 \\
\hline $\begin{array}{l}\text { Souvenir stores offer discounts when buying more than one } \\
\text { item or discounts for groups }\end{array}$ & 3.48 & 0.87 & 0.753 \\
\hline Souvenir stores provide credit card payment facilities & 2.63 & 0.78 & 0.823 \\
\hline
\end{tabular}

The data in table (4) shows the respondents' answers on the dimensions of innovation in price, and most of the answers reflect an average agreement where the arithmetic mean of this dimension was (3.36), and the standard deviation (0.98). The highest average value was (4.20) for the phrase related to the discrepancy in the prices of tourist souvenirs between stores, reflecting the absence of control over the pricing of tourist souvenirs in the markets. This can be explained by the fact that those in charge of the tourism souvenir activity are not very interested in innovation in the field of price, and their innovation 2020 | Journal of Sustainable Tourism and Entrepreneurship/ Vol 2 No 1, 15-29 
in this aspect is limited to set special discounts for groups or when purchasing more than one item. The majority of the respondents agreed that there is a difference in souvenir prices among stores, which confirms what was stated in the study by Dawood and Bahaa (2019), where more than 70\% of the study sample agreed that there is a big discrepancy in prices from one store to another.

Table 5. Innovation in promotion in souvenir stores

\begin{tabular}{|l|c|c|c|}
\hline \multicolumn{1}{|c|}{ Innovation in promotion dimensions } & Mean & $\begin{array}{c}\text { Standard } \\
\text { deviation }\end{array}$ & $\begin{array}{c}\text { EFA factor } \\
\text { Loading }\end{array}$ \\
\hline $\begin{array}{l}\text { You know about souvenir stores through various } \\
\text { advertisements }\end{array}$ & 2.10 & 0.71 & 0.654 \\
\hline Hotels provide ads for their souvenir stores & 2.97 & 0.92 & 0.542 \\
\hline $\begin{array}{l}\text { Information about Egyptian handicrafts and souvenirs and } \\
\text { their locations is available on the Internet }\end{array}$ & 2.83 & 0.99 & 0.945 \\
\hline $\begin{array}{l}\text { Information about Egyptian handicrafts and their locations } \\
\text { is available in the tourist brochures }\end{array}$ & 2.33 & 0.89 & 0.888 \\
\hline Souvenir stores offers attractive and intriguing ads & 3.23 & 0.91 & 0.792 \\
\hline $\begin{array}{l}\text { Souvenir stores frequently offer free services in order to } \\
\text { stimulate sales }\end{array}$ & 2.27 & 0.68 & 0.655 \\
\hline Souvenir stores offer different promotions & 2.33 & 0.74 & 0.609 \\
\hline
\end{tabular}

The data in table (5) shows that the respondents' answers to the phrases related to the dimension of innovation in promotion tend to be highly "disagree" with a mean (2.58) and a standard deviation (0.93). Therefore, these answers reflect a low agreement to this dimension, meaning that the respondents do not consider that there is enough innovation in the adopted promotional methods in souvenir stores in Egypt.

These results are consistent with the findings of the study by Dawood and Bahaa (2019) that $41.9 \%$ of the study respondents were exposed to fraud by receiving wrong information about the tourist souvenirs in the markets due to the lack of reliable sources about the products offered in the tourist markets in Egypt.

Table 6. Innovation in place/distribution channels

\begin{tabular}{|l|c|c|c|}
\hline \multicolumn{1}{|c|}{ Innovation in place dimensions } & Mean & $\begin{array}{c}\text { Standard } \\
\text { deviation }\end{array}$ & $\begin{array}{c}\text { EFA factor } \\
\text { Loading }\end{array}$ \\
\hline Souvenir stores in Egypt have a modern appearance & 2.38 & 0.81 & 0.713 \\
\hline $\begin{array}{l}\text { Souvenir stores place indicative signs inside and outside the } \\
\text { store to make it easier for customers }\end{array}$ & 2.24 & 0.85 & 0.853 \\
\hline Souvenir stores' locations are easy to access & 2.79 & 1.10 & 0.734 \\
\hline Souvenirs are arranged in stores selectively and neatly & 2.47 & 0.92 & 0.655 \\
\hline $\begin{array}{l}\text { Stores display souvenirs to show a variety of ways to use and } \\
\text { display at home. For example, display clay pitchers to } \\
\text { illustrate multiple uses: to serve lemonade, hold flowers, and } \\
\text { add to a grouping of decorative items. }\end{array}$ & 2.32 & 0.73 & 0.896 \\
\hline
\end{tabular}


The data in table (6) shows that the respondents' answers to the phrases related to the dimension of innovation in place (souvenirs stores) tend to be highly "disagree" with a mean (2.59) and a standard deviation (0.97). Therefore, these answers reflect a low agreement to this dimension, meaning that the respondents do not consider enough innovation in the adopted promotional methods in Egypt's souvenir stores.

In general, the respondents' answers reflect a low agreement on the dimension of innovation in place/ distribution channels, and the explanation for this is that those in charge of the tourist souvenir activity do not pay attention to innovate in distribution policies in a way that helps to reduce customers' time and efforts. The respondents' answers about the absence of indicative signs in the tourist markets are consistent with the results of a study by Radwan and Jones (2015), which concluded that there are no signs to show tourists the route, history, or description of Khan al-Khalili Market, so it becomes easy for tourists to stray their way in the narrow alleys of the market, besides, there were no signs about the bathrooms in the market, or how to get there.

In general, the arithmetic mean of all creative marketing dimensions is (2.59) with a standard deviation (1.06), and according to a five-point Likert scale, we conclude that the degree of approval of the respondents on this variable was low, indicating that the respondents consider that the tourist souvenir activity lacks innovative marketing policies.

\subsection{The availability of competitive advantages in the Egyptian tourist souvenir activity}

Table 7. The dimensions of competition in Egyptian souvenirs

\begin{tabular}{|c|c|c|c|c|}
\hline & Competition dimensions & Mean & $\begin{array}{l}\text { Standard } \\
\text { deviation }\end{array}$ & $\begin{array}{c}\text { EFA } \\
\text { factor } \\
\text { loading }\end{array}$ \\
\hline \multirow{2}{*}{ Cost } & $\begin{array}{l}\text { Souvenirs are available in Egypt at relatively low } \\
\text { prices }\end{array}$ & 2.04 & 0.96 & 0.865 \\
\hline & $\begin{array}{l}\text { The prices of the souvenirs shown are commensurate } \\
\text { with their quality }\end{array}$ & 2.60 & 1.03 & 0.984 \\
\hline \multirow{3}{*}{ Quality } & Egyptian souvenirs are of good quality & 1.61 & 1.10 & 0.987 \\
\hline & $\begin{array}{l}\text { Souvenir stores are interested in taking customers' } \\
\text { opinions about the required levels of quality }\end{array}$ & 1.97 & 0.76 & 0.844 \\
\hline & $\begin{array}{l}\text { Salespeople at souvenir stores have good sales } \\
\text { performance and skills }\end{array}$ & 3.55 & 0.77 & 0.659 \\
\hline Time & $\begin{array}{l}\text { Souvenir stores deliver products in a short time and } \\
\text { on time }\end{array}$ & 2.35 & 0.82 & 0.955 \\
\hline \multirow{2}{*}{ Flexibility } & $\begin{array}{l}\text { Souvenir stores compensate customers when a } \\
\text { mistake or a problem occurs }\end{array}$ & 2.35 & 0.75 & 0.873 \\
\hline & $\begin{array}{l}\text { Souvenir stores make changes and modifications to } \\
\text { products according to customers' desires }\end{array}$ & 2.42 & 0.87 & 0.925 \\
\hline \multirow{2}{*}{$\begin{array}{l}\text { Uniqueness } \\
\text { and special } \\
\text { features }\end{array}$} & $\begin{array}{l}\text { Egyptian souvenirs are unique and distinguished } \\
\text { from other souvenirs }\end{array}$ & 3.23 & 0.99 & 0.812 \\
\hline & Pharaonic souvenirs are especially attractive & 3.87 & 0.78 & 0.785 \\
\hline
\end{tabular}

The data in table (7) shows the opinions of the respondents on the second variable of the study concerning the competitive advantage of the Egyptian souvenirs, the answers of the respondents tended 
to highly disagree with the dimensions of cost, quality, time and flexibility. As for the uniqueness of the Egyptian souvenirs, the answers tended towards medium agreement.

In general, the opinions of the respondents on the variable of the competitive advantage of tourist souvenirs in Egypt tended towards a low agreement with a mean (2.60) and a standard deviation (1.12). This can be explained by the fact that the activity of tourist souvenirs in Egypt does not achieve the proper competitive advantages that qualify it to stand in front of the competition. The respondents' answers to the phrase related to the prices of tourist souvenirs are consistent with what was shown by the study of Radwan and Jones (2015) that there is an exaggeration in the prices of tourist souvenirs in Khan Al-Khalili Market, which led tourists to turn away and refrain from buying.

The answers to the phrase related to the attractiveness of Pharaonic souvenirs are consistent with the study results by Dawood and Bahaa (2019), which showed that $40 \%$ of the respondents prefer to buy tourist souvenirs from statues, pharaonic souvenirs, and papyrus.

\subsection{Hypotheses testing}

To identify the extent of a correlation between innovative marketing and enhancing the competitive advantage of tourist souvenirs in Egypt and test the validity of the main hypothesis, an ANOVA regression variance was analyzed.

Table 8. Simple regression analysis to test the impact of innovation marketing on competitive advantage

\begin{tabular}{|l|c|c|c|c|c|c|}
\hline Independent variable & $\mathrm{F}$-value & $\mathrm{sig}$ & $\mathrm{R}$ & $\mathrm{R}^{2}$ & $\mathrm{~T}$-value & $\mathrm{B}$-value \\
\hline Innovative marketing & 27.597 & $0.000^{*}$ & 0.975 & 0.951 & 7.63 & 0.525 \\
\hline$(\alpha=0.05)$
\end{tabular}

Through table (8) it is evident that there is a relationship between the independent variable, which is an innovative marketing and the dependent variable which is competitive advantage, and the strength of the relationship between the two variables was $97.5 \%$. The competitive advantage variable explained $95.1 \%$ of the variance in the level of innovative marketing based on $\mathrm{R}^{2}$.

Therefore, the main hypothesis is correct, meaning that there is a significant role with statistical significance for innovative marketing in enhancing the competitive advantage of tourist souvenirs in the Egyptian tourist destination at a significance level $(\alpha=0.05)$.

Table 9. Simple regression analysis to test Sub-hypotheses

\begin{tabular}{|l|c|c|c|c|c|c|}
\hline Independent variable & $\mathrm{F}$-value & $\mathrm{sig}$ & $\mathrm{R}$ & $\mathrm{R}^{2}$ & T-value & B-value \\
\hline Product innovation & 24.926 & $0.000^{*}$ & 0.606 & 0.367 & 4.993 & 0.693 \\
\hline Innovation in price & 5.476 & $0.021^{*}$ & 0.343 & 0.118 & 2.397 & 0.386 \\
\hline Innovation in promotion & 9.709 & $0.003^{*}$ & 0.429 & 0.184 & 3.116 & 0.402 \\
\hline Innovation in place & 14.062 & $0.001^{*}$ & 0.496 & 0.246 & 3.750 & 0.457 \\
\hline
\end{tabular}

$(\alpha=0.05)$

The first sub-hypothesis

Table (9) shows that there is a relationship between the independent variable, which is product innovation and the dependent variable, which is the competitive advantage, and the strength of the relationship between the two variables was $60.6 \%$. The competitive advantage variable was explained by $36.7 \%$ of Variation in product innovation level depending on $\mathrm{R}^{2}$. Thus we accept the first subhypothesis. 
The second sub hypothesis

The table shows that there is a relationship between the independent variable, which is innovation in price and the dependent variable, which is the competitive advantage, and the strength of the relationship between the two variables was $34.3 \%$, and the competitive advantage variable was explained by $11.8 \%$ from the variance in the level of innovation in price based on $\mathrm{R}^{2}$. Therefore we accept the second sub-hypothesis.

\section{The third sub-hypothesis}

The table shows that there is a relationship between the independent variable, which is innovation in the promotion and the dependent variable, which is the competitive advantage, and the strength of the relationship between the two variables was $42.9 \%$, and the competitive advantage variable was explained by $18.4 \%$ from the variation in the level of innovation in promotion based on $\mathrm{R}^{2}$. Thus, we accept the third sub-hypothesis.

\section{The fourth sub-hypothesis}

The table shows that there is a relationship between the independent variable, which is innovation in place and the dependent variable which is the competitive advantage, and the strength of the relationship between the two variables was $49.6 \%$, and the competitive advantage variable was explained by $24.6 \%$ of Variation in the level of innovation in place depending on $\mathrm{R}^{2}$. Thus, we accept the fourth subhypothesis.

\section{Conclusion}

The main purpose of the study was to investigate the relationship between innovative marketing and enhancing the competitive advantage of souvenirs in the Egyptian tourist destination. Because of the importance of tourist souvenirs as a component of the tourism industry that can help to distinguish the tourist destination and contribute to the national economy, it is essential to pay more attention to innovate in the marketing mix of tourist souvenirs, especially with the existence of high competition with other neighboring countries in addition to the imported cheap products that lack authenticity. The results of the study indicated that there is a significant role with statistical significance for innovative marketing in enhancing the competitive advantage for tourist souvenirs in Egypt. The results as well showed that there is a lack of innovation within the marketing mix of tourist souvenirs in Egypt which led to not achieving the proper competitive advantage that could help tourist souvenir activity in Egypt to stand in front of the competition.

Based on the outcomes of this study, several recommendations could be produced as follows:

i. Creating a marketing department within the Egyptian Chamber of Tourists Commodities, to undertake innovation studies in the marketing mix of tourist souvenirs and to share these studies with the training committee at the Ministry of Tourism to train the owners of tourist souvenirs stores on the latest innovative marketing methods.

ii. Activating a committee to control the quality of souvenirs in tourist souvenir stores, in addition to monitor prices and solve the problem of price discrepancies between stores.

iii. Studying the targeted markets as well as the competitors' markets to find out the most important developments and work to devise new policies to confront competition and attract tourists.

iv. Continuously conducting surveys to find out the tourists 'opinions on the souvenirs presented, as well as their desires and future aspirations.

v. Creating a balance in innovation between the various fields of marketing and not focusing on one aspect only.

vi. Providing training courses on communication and presentation skills aimed at salespersons in tourist souvenir stores in order to enhance their communication with tourists and to ensure that they provide distinctive service to tourists.

vii. Providing indication signs in different languages in the tourist markets to make it easier for the tourists, as well as providing information on the historical background of the market. 
viii. Promote products that reflect the destination's local and cultural heritage instead of relying on the imported Chinese products.

\section{Implications}

Theoretically, this study contributes to the tourism literature concerning by introducing a new vision of improving the tourist souvenirs in a way that satisfies the tourists and accomplishes their desires and attracts new tourists. In addition to that, the study highlighted the importance of innovating in the marketing mix of tourist souvenirs and its role in enhancing the competitive advantage of any tourist destination. The findings of this study revealed the souvenir marketing mistakes that need to be corrected to introduce a better product to the tourists.

\section{Limitation and study forward}

Whereas the study targeted tourists visiting souvenir stores, the study only covered tourists in two main tourist governorates in Egypt which are South Sinai and the Red Sea, because of the repercussions of the COVID-19 virus crisis, as tourist souvenirs stores were allowed to operate in accordance with the precautionary measures in only three main governorates: the Red Sea, South Sinai, and Marsa Matrouh, in addition to some gift shops in major hotels. Further studies should be conducted targeting different areas in the tourist destination. The current study as well did not investigate the reasons behind the shortage of marketing methods within souvenir stores, so this gap should be covered by further studies.

\section{References}

Alsamydai, M., Alnawas, I., \& Yousif, R. (2010). The impact of marketing innovation on creating a sustainable competitive advantage: the case of private commercial banks in Jordan. Asian Journal of Marketing, 4, 113-130.

Awwad, A., Khattab, A., \& Anchor, J. (2013). Competitive Priorities and competitive advantage in Jordanian manufacturing, Journal of Service Science and Management, 6(1), 6979. doi: 10.4236/jssm.2013.61008.

Cascio, R., (2011), Marketing innovation and firm performance: research model, research hypothesesm and managerial implications (Doctoral dissertation, College of Business Administration, University of Central Florida, Orlando, Florida). Retrieved from: http://etd.fcla.edu/CF/CFE0003956/Cascio Robert P 201108 PhD.pdf

Cegliński, P. (2017). The concept of competitive advantages. logic, sources and durability. Journal of Positive Management, 7(3), 57-70.

Dawood, N., \& Bahaa, R. (2019). The Role of souvenirs and handicrafts in achieving tourists' satisfaction applied on Luxor city, Research Journal of the Faculty of Tourism and Hotels ,Mansoura University, 6(6), 65-106.

Dirisu, J., Iyiola, O., and Ibidunni, O. (2013). Product differentiation: a tool of competitive advantage and optimal organizational performance (a study of Unilever Nigeria Plc), European Scientific Journal, ESJ, 9(34).

Dumbrovska, V., and Fialova,D. (2019). The city of one hundred souvenir shops: Authenticity of souvenirs in Prague, Journal of Tourism and Cultural Change, 18(3)

El Samadicy, A., and Amara, D. (2011). Tourists' souvenir buying behavior and retailers' consciousness of Egypt visitors souvenir buying profile. Advances in Hospitality and Tourism Marketing and Management AHTMM conference, Istanbul, Turkey . Retrieved from : https://ahtmm.emu.edu.tr/Documents/previous-conferences/2011-part3.pdf

Gahring, S., Niemeyer, S., Reilly, R., \& Stout, J. (1992). Marketing crafts and other products to tourists. North Central regional extension publication, Cooperative Extension Service.

Haddad, S., \& Algadeer, H. (2004). An empirical investigation on the impact of innovation within organizations on marketing innovation, Jordan Journal of Applied Science, 7, 77-95

Heroux, L., \& Gultek, M. (2016), Antique shops' marketing strategies in rural tourism destinations: a comparative exploratory study in the U.S. and Canada, Journal of Tourism and Hospitality Management, 4(2).

Hinterhuber, A., \& Liozu, S. M. (2014). Is innovation in pricing your next source of 
competitive advantage?. Business Horizons, 57(3), 413-423.

doi:10.1016/j.bushor.2014.01.002

Hosseini, A., Soltani, S., \& Mehdizadeh, M., (2018). Competitive advantage and its impact on new product development strategy (Case study: Toos Nirro Technical Firm). Journal of Open Innovation: Technology, Market, and Complexity, 4(2), 1-12

Ibrahim, J., Hilaly, H., \& Morsy, N. (2018). The role of brand authenticity as a part of contemporary marketing in Egyptian destination marketing. Journal of The Faculty of Tourism and Hotels, Alexandria university, 15(1), 29-42

Ilic, D., Ostojic, S., \& Damnjanovic, N. (2014). The importance of marketing innovation in new economy. Singidunum Journal of Applied Sciences, 11(1), 34-42

Ionescu, A., \& Dumitru, N. (2015). The role of innovation in creating the company's competitive advantage, EcoForum, 4(1), 99.

Jitpaiboon, T. (2014). The study of competitive priorities and information technology selection: exploring buyer and supplier performance, Journal of International Technology and Information Management, 23(3), Article 6. Available at: http://scholarworks.lib.csusb.edu/jitim/vol23/iss3/6

Krajewsky, L., Malhotra, M., \& Ritzman, L. (2012). Operations management: processes and supply chains. 10th Edition, Pearson Education Limited, Harlow, England

Kuswantoro, F., Mohd, R. M., Abdul, R., \& Ghorbani, H. (2012). Impact of distribution channel innovation on the performance of Small and Medium Enterprises. International Business Management, 5, 52-61.

Mahasuar, K. (2019). Strategic innovations in distribution channels - an emerging market perspective and case studies from consumer packaged goods (CPG) industry of India", Strategic Direction, 35(1), 13-16.

Marzouki, S. H. (2020). Studying the vital role of souvenirs industry as an essential component of tourist experience: a case study of the United Arab Emirates (UAE). Journal of Tourism, Hospitality and Sports, 46, 24-33

Mburu, P. (2016). relationship between innovation strategies and competitive advantage in the logistics firms in Mombasa County, Kenya. Unpublished Master Thesis, University of Nairobi.

Retrieved from http://erepository.uonbi.ac.ke/handle/11295/98589

Quporsi, T. (2010). The role of marketing creativity and innovation in achieving competitive advantage for banks. International Business Management, 4(2), 53-56.

Radwan, W., \& Jones, C. (2015). Improving souvenir sales in tourism: a case study of Khan El-Khalili Market, International Academic Journal of the Faculty of Tourism and Hotel Management, 1(1), 201-222

Reguia, C. (2014). Product innovation and the competitive advantage. European Scientific Journal, ESJ, 10(10). Retrieved from: https://doi.org/10.19044/esj.2014.v10n10p\%p

Sattari, B., \& Mehrabi, J. (2016), Model of marketing innovative strategies in international entrepreneurship: a global business environment. Asian Social Science, Canadian Center of Science and Education, 12(10) 76-91

Singh, M. (2018). Understanding souvenir as an essential instrument for guiding tourists: A Conceptual framework. Journal of Tourism Intelligence and Smartness, 1(2), 75-87

Souvenir. (n.d.). In Macmillan dictionary. Macmillan Education Limited. Retrieved March 21, 2021, from: https://www.macmillandictionary.com/dictionary/british/souvenir

Swanson, K. (2004). Tourists' and retailers' perceptions of souvenirs. Journal of Vacation Marketing, 10(4), 363-377

Urbancova, H. (2013. Competitive advantage achievement through innovation and Knowledge. Journal of Competitiveness, 5, 82-96.

Wicks, B. (2004). Direct marketing of crafts and souvenirs to Vladimir Visitors. A Project undertaken by the Department of Recreation, Sport and Tourism, University of Illinois

Wilkins, H. (2010). Souvenirs: what and why we buy. Journal of Travel Research, 50(3), 239-247

Yoshyuki, I. (2010). Marketing strategy for souvenirs in Kyoto: a feasibility study of Blue 
Ocean Strategy in Tourism, Journal of Ritsumeikan Social Sciences and Humanities, 2, 127

Zulaikha, E., \& Bereton, M. (2011). Innovation strategies for developing the traditional

souvenir craft industry, In Cowled, C J L (Ed.) Proceedings of the first international conference on engineering, designing and developing the built environment for sustainable wellbeing. Queensland University of Technology, Australia, pp. 53-58. 